Удк 332.1

В.В. Калюжный

Ассоциация «Бизнес-клуб «Авангард»

Владивосток. Россия

Обеспечение условий для сохранения и увеличения «среднего класса» в численности населения ДВФО как инструмент экономической безопасности в стратегии развития региона

V.V. Kalyuzhny

Association "Business Club"Avangard"

Vladivostok. Russia

\title{
Ensuring conditions for the preservation and increase of the "middle class" in the population of the FEFD as an instrument of economic security in the development strategy of the region
}

Многие ученые утверждают и мировая практика свидетельствует о том, что без среднего класса нельзя выйти из экономического кризиса. Однако проблема формирования среднего класса комплексная и связана с проблемой восстановления социальной стратификации нашего общества. Средний класс - основа стабильности высокоразвитых стран. Потребительские запросы среднеобеспеченных слоев населения во многом определяют развитие экономики. Средний класс - основной хранитель общественных отношений, носитель господствующей идеологии, всей системы ценностей. Представляя собой как бы экономическую и социально-политическую медиану общества, средний класс стратегически нацелен на сохранение сложившегося статус-кво и поэтому служит основой общественного и политического консенсуса.

С экономической точки зрения средний класс - это преобладающая (массовая) часть экономически активного населения, которая имеет возможность производительно трудиться и воплощать заработанные средства в материальные блага.

Относительно существования среднего класса в России наличествуют различные, зачастую прямо противоположные мнения: нет среднего класса вообще, в западном понимании, или же средний класс у нас все-таки существует? Разработаны разные методы оценки среднего класса. В США, например, оценка основана на показателе годового дохода (известны методики оценки по имуществу,

Калюжный Валерий Владимирович - президент Ассоциации «Бизнес-клуб «Авангард». 
накоплениям, собственности). Так, в США и Европе средний класс составляет 60-70\% населения.

Имеют место попытки определения среднего класса и в России. По оценке Института современного развития, к классическому среднему классу развитых стран можно отнести только 7\% россиян. Критерии для данной оценки приняты как совокупность постоянного месячного дохода на каждого члена семьи в эквиваленте 2-2,5 тыс. долл., не менее 40 квадратных метров общей площади на каждого члена семьи и 2-3 легковые машины на семью.

Согласно отчету «Global Wealth Report 2015» швейцарского банка Credit Suisse, в 2015 г. к среднему классу и выше в России можно было отнести 4,1\% взрослого населения или около 5 млн человек, имевших доход от 18000 долл. США в год. При этом отмечено, что число представителей среднего класса в России уменьшилось по сравнению с 2000 годом (5,6 млн человек). По мнению социологов, эта цифра завышена, поскольку многие причисляют себя к среднему классу не по доходам, а «по самоощущению» (например, потому, что имеют высшее образование, преподают в университете, пользуются уважением в обществе и пр.).

Таким образом, серьезно говорить о наличии среднего класса в России пока рано. В нашей стране складывается социальная структура, характерная для слаборазвитых государств, где нет среднего класса, а социальная структура размывается и теряет стратификационный характер. Тем не менее, российское правительство разрабатывает механизмы по привлечению и созданию условий для населения, кого можно было бы причислить к среднему классу. В частности, в Стратегии социально-экономического развития Дальнего Востока и Байкальского региона на период до 2025 года заложены предпосылки для притока и удержания населения в ДВФО [1].

«Стратегической целью развития Дальнего Востока и Байкальского региона является реализация геополитической задачи закрепления населения на Дальнем Востоке и в Байкальском регионе за счет формирования развитой экономики и комфортной среды обитания человека в субъектах Российской Федерации, расположенных на этой территории, а также достижения среднероссийского уровня социально-экономического развития» [1].

Территория Дальнего Востока, составляющая 6952 тыс. кв. км (40,6 \% территории Российской Федерации), включает в себя 12 субъектов Российской Федерации: Республика Саха (Якутия), Камчатский, Приморский, Хабаровский края, Амурская, Магаданская, Сахалинская области, Еврейская автономная область, Чукотский автономный округ, Республика Бурятия, Забайкальский край и Иркутская область.

Природно-климатические условия на большей части территории региона характеризуются как весьма суровые и даже экстремальные. Только на юге Приморского края среднегодовая температура превышает нулевую отметку. Богатые природные ресурсы общемирового значения привлекают к Дальнему Востоку и Байкальскому региону внимание всех государств, особенно стран Азиатско-Тихоокеанского региона. Однако ресурсный потенциал Дальнего Востока в силу объективных и субъективных причин используется далеко не полностью. 
Опережающее развитие стран Азиатско-Тихоокеанского региона в сравнении с общемировыми показателями заставляет по-новому взглянуть на место Дальнего Востока в политическом, экономическом и социальном развитии России, на роль региона для России с глобальной точки зрения в стратегической перспективе.

Производительность труда в расчете на одного занятого в экономике Дальнего Востока в 4 раза ниже, чем в Японии, в 6 раз ниже, чем в США, в 2,5 раза ниже, чем в Южной Корее, в 5 раз ниже, чем в Австралии и в целом ниже среднероссийской. Потребление первичных энергоресурсов на территории на единицу валового регионального продукта в 2,5 раза выше, чем в среднем по Российской Федерации, электрической энергии - в 1,8 раза, нефтеёмкости - в 2 раза. Структура топливно-энергетического баланса крайне не эффективна. Степень интегрированности экономики субъектов Российской Федерации, расположенных на территории Дальнего Востока, можно охарактеризовать как невысокую. В большей степени интегрированы отдельные южные территории Дальнего Востока, имеющие единую транспортную и энергетическую инфраструктуру.

Место Дальнего Востока в глобальной экономике невозможно представить без учета оценки потенциала, тенденций развития и потребностей стран АзиатскоТихоокеанского региона, а также экономики ведущих стран мира. В настоящее время резко возросла роль простых ресурсов: земли, воды, дикой природы, а потенциал простых ресурсов таких бурно развивающихся стран АзиатскоТихоокеанского региона, как Китай, Индия, Южная Корея и Сингапур, практически исчерпан.

Конкурентные преимущества Дальнего Востока - это, прежде всего, экономико-географическое расположение (в первую очередь кратчайшие транспортные маршруты Восток - Запад) в Азиатско-Тихоокеанском регионе, огромные запасы природных ресурсов (рудные и нерудные полезные ископаемые, водные биологические ресурсы, гидроэнергетические, лесные, рекреационные и другие ресурсы), наличие протяженного морского побережья и внешней границы как возможности для социально-экономического сотрудничества, развитой «базовой» портовой инфраструктуры, привлекательных туристических активов, а также близость к крупнейшим мировым туристическим рынкам.

С 1991 года численность населения территории Дальнего Востока начала сокращаться, причем депопуляция значительно опережала среднероссийские темпы. Основной причиной сокращения численности населения является миграция, на которую накладываются неблагоприятные тенденции естественного движения населения (превышение смертности над рождаемостью). За период 1991-2007 гг. субъекты Российской Федерации, расположенные на территории Дальнего Востока, потеряли 1,5 млн человек, из которых на миграционный отток пришлось более 1,3 млн человек. За тот же период в Байкальском регионе потери населения составили около 600 тыс. человек.

В среднесрочной и долгосрочной перспективе главными условиями развития Дальнего Востока станут сохранение и развитие трудовых ресурсов посредством эффективного внутреннего перераспределения трудовых ресурсов, при- 
влечения и закрепления кадров из других субъектов Российской Федерации и зарубежных стран, повышения качества рабочей силы.

Целью развития социальной инфраструктуры являются создание системы доступного и высококачественного высшего образования, повышение доступности специализированной, в том числе высокотехнологичной, медицинской помощи, поддержка формирования развитой региональной и местной инфраструктуры в области здравоохранения, социальной защиты, образования, культуры, обеспечения досуга, а также содействие обеспечению граждан комфортным жильем и жилищно-коммунальными услугами, стимулирование преобразования среды проживания населения. При этом качество и доступность услуг должны превышать среднероссийский уровень для компенсации неблагоприятных природных, климатических и географических условий проживания населения.

Государственная политика в сфере образования на территории региона будет нацелена на обеспечение доступности дошкольного образования, повышение качества общего образования, восстановление системы начального, среднего профессионального образования, а также дополнительного образования, развитие высшего образования. Кроме того, будет сформирована система непрерывного образования.

Высокое значение имеет привлечение в отрасль квалифицированных специалистов, поэтому особое внимание будет уделено развитию системы подготовки педагогических кадров. Развитие системы высшего образования на территории Дальнего Востока связано с созданием крупнейших образовательных центров (одним из которых является Дальневосточный федеральный университет), способных обеспечить прорыв в инновационных технологиях.

Развитие системы здравоохранения должно преследовать следующие цели: преломление тенденций естественной убыли населения (снижение уровня смертности в трудоспособном возрасте, снижение младенческой, детской и материнской смертности) и снижение уровня заболеваемости.

Государственная политика в сфере работы с молодежью будет нацелена на развитие программ социального просвещения по всем вопросам жизни молодежи в обществе (здоровье, спорт, образование, жилье, досуг, труд, карьера, общественная жизнь, семья, международные отношения, жизнь молодежи в других странах и др.), расширение сети учреждений по работе с молодежью, оказание информационно-консалтинговой помощи молодежи, разработку специальных проектов, уравнивающих возможности молодежи, проживающей в сельских и удаленных районах, развитие эффективных моделей и форм вовлечения молодежи в трудовую и экономическую деятельность, включая деятельность трудовых объединений, студенческих отрядов, развитие молодежных бирж труда и других форм занятости молодежи, реализацию программ поддержки молодежного предпринимательства, в том числе в инновационных секторах экономики.

Государственная политика в сфере физической культуры и спорта будет ориентирована на повышение интереса жителей Дальнего Востока и Байкальского региона к регулярным занятиям физической культурой и спортом, пропаганду спорта как основы здорового образа жизни. Для повышения комфортности 
среды обитания предлагаются меры государственного регулирования и поддержки комплексной застройки населенных пунктов с созданием рекреационных и спортивных зон площадью 1,5-5 га в жилых микрорайонах и пригородах областных и районных центров.

Активизируются усилия сотрудников социальной защиты и общественности по выявлению людей и семей, находящихся в неблагоприятной жизненной ситуации, будет расширен спектр деятельности комплексных центров социального обслуживания населения по социальной адаптации.

Ключевыми направлениями социальной защиты являются укрепление института семьи как основы стабильности общества, создание системы комплексной поддержки семьи (обеспечение жильем, работой, медицинским и социальным обслуживанием) и специализированных учреждений социальной помощи семье и детям. Предусмотрены также дополнительные меры по стимулированию переселения соотечественников, проживающих за рубежом, в субъекты Российской Федерации, расположенные на территории Дальнего Востока.

В целом, мы видим, что государство идёт по пути выработки решений и будем надеяться, что эти усилия приведут к желаемому результату.

1. О Стратегии социально-экономического развития Дальнего Востока и Байкальского региона на период до 2025 г.: распоряжение Правительства РФ от 28 декабря 2009 г. № 2094-p [Электронный pecypc]. URL: https://www.garant.ru/products/ipo/prime/ doc/6632462/

\section{Транслитерация}

1. O Strategii social'no-e`konomicheskogo razvitiya Dal'nego Vostoka i Bajkal`skogo regiona na period do 2025 g.: rasporyazhenie Pravitel'stva RF ot 28 dekabrya 2009 g. № 2094-r [E`lektronny`j resurs]. URL: https://www.garant.ru/products/ipo/prime/ doc/6632462/

() В.В. Калюжный, 2019

Для цитирования: Калюжный В.В. Обеспечение условий для сохранения и увеличения «среднего класса» в численности населения ДВФО как инструмент экономической безопасности в стратегии развития региона // Территория новых возможностей. Вестник Владивостокского государственного университета экономики и сервиса. 2019. Т. 11, № 2. C. 19-23.

For citation: Kalyuzhny V.V. Ensuring conditions for the preservation and increase of the "middle class" in the population of the FEFD as an instrument of economic security in the development strategy of the region, The Territory of New Opportunities. The Herald of Vladivostok State University of Economics and Service, 2019, Vol. 11, № 2, pp. 19-23. 